\title{
Comparative studies on mixed fruit jam packaged in different local containers
}

\author{
*Adebayo F. O'. and Abdus Salam R. O². \\ ${ }^{1}$ Department of Microbiology (Food and Industrial Microbiology), Nassarawa State University, Keffi, Nassarawa state, \\ Nigeria \\ ${ }^{2}$ Department of Food Technology, Lagos State Polytechnic, Ikorodu, Lagos state, Nigeria \\ *Corresponding Author's Email: fattysocioscope@yahoo.com
}

\begin{abstract}
As Nigeria is a producer of abundant fresh fruits but has effective preservation and packaging challenge, this work aims to compare some quality factors of mixed fruit Jam that was packaged in different locally available containers for a 15-month storage period at room temperature. Virtual inspection, $\mathrm{pH}$, moisture content, total soluble solids and microbiological assessment of the samples were conducted to determine their keeping quality. Sensory evaluation was also conducted to determine the acceptability of the packaged samples. The result showed that after the 15-month storage at room temperature, gel consistency of the samples were maintained in the plastic plates and glass jar packages, while the samples in sachet water pouch and polythene packages became runny. The $\mathrm{pH}$ of the samples was between 3.4-3.5. The moisture content was between $28-37 \%$ while the total soluble solids was between $63-72 \%$. The total microbial counts of all the samples after 15 -months storage were within the acceptable range of $1 \times 10^{3} \mathrm{cfu} / \mathrm{ml}$. There was no fungal growth in all the packaged samples except in the transparent plastic plate that exhibit a growth of $6 \times 10^{2}$. There was no bacterial and coliform growth in all the packaged samples. The result of the sensory evaluation shows that glass jar and white plastic plate with screw cover container were significantly $(p=0.05)$ more acceptable for packaging Jam spread than those in the other containers used. Hence, it was concluded that some locally available packages can be used for packing shelfstable small scale Jam production for in a developing nation.
\end{abstract}

Keywords: Fruit preserves, Jam, Packages, Gel consistency, shelf-life, pH, TSS.

\section{INTRODUCTION}

Nigeria is an agriculturally active nation that is blessed with abundant fertile land for food production. During the rainy season, large quantities of various fruits are harvested mainly for retail consumption. A considerable amount of such fruits get spoilt before they are sold, while others are lost at the end users table due to the highly perishable nature of the commodity. Consequently, one method of economically reducing post-harvest losses of

\section{ABBREVIATION}

WJ white plastic plate with screw cover

TJ transparent plastic plate with pull-press cover

SJ sachet water package

PJ polythene pouch

GJ glass jar

TSS total soluble solids

GSO Gulf Standard Organization fruits is by preserving it in high-sugar syrup, known as fruit preserves. Jam, jelly and marmalade are the common fruit preserve that can easily be produced at the small and medium scale for wealth creation in a developing economy.

However, there has been a challenge of packaging of locally manufactured preserves for commercialization, as the usual packages for such products are imported glass jars that are not readily available and affordable to an average local producer. This led to the exploration of other options that are more economical, such as plastic tubs that have lower production and distribution costs in Uganda (United Nations Industrial Development Organization, UNIDO, 2004). Re-used containers are also collected, but great care is needed to ensure that they are properly cleaned and sterilized. Also used are pots that are sealed with a foil lid or with a snap-on plastic lid, and plastic film. 


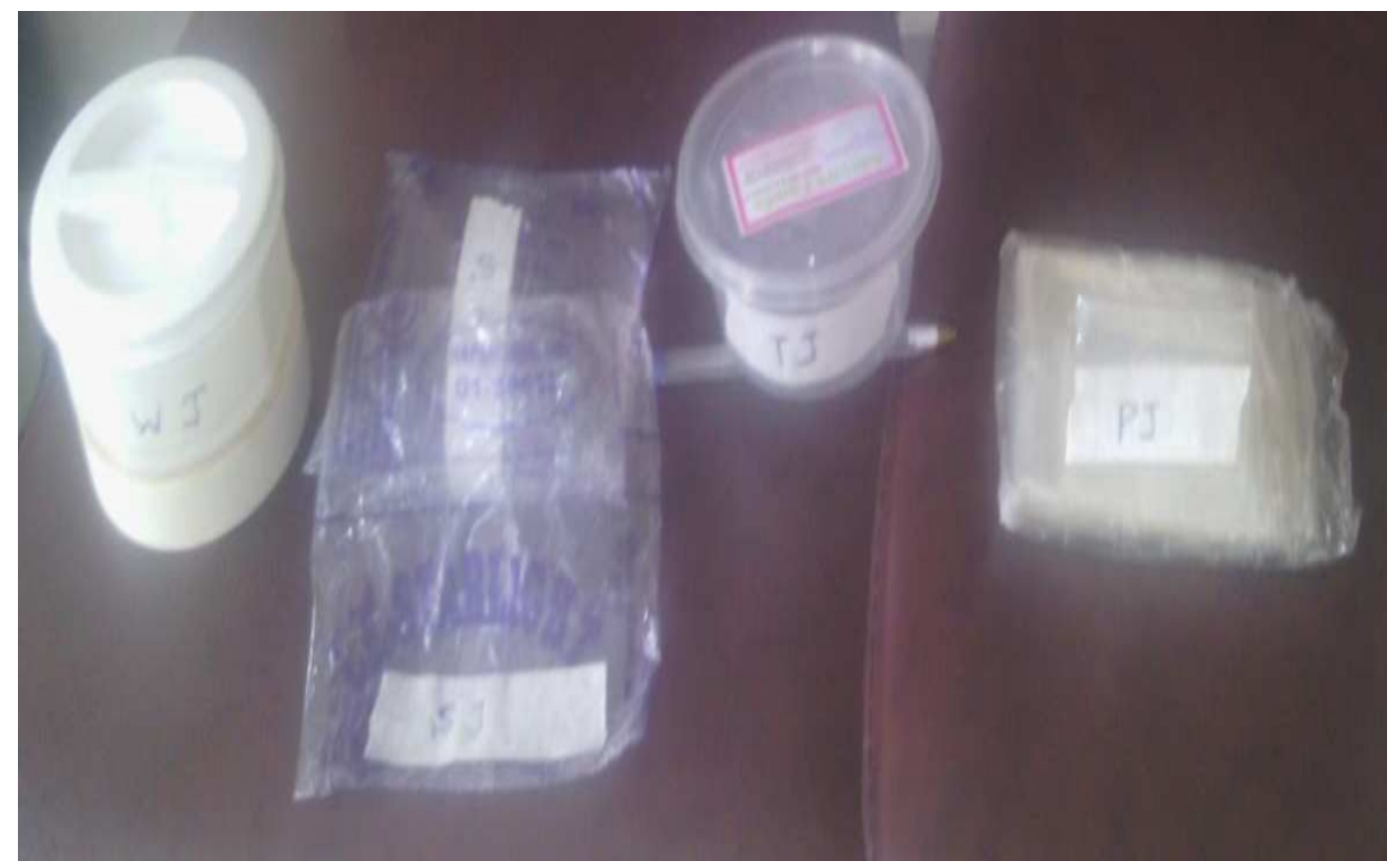

Figure 1. The different locally available containers used in the study. From left to right: WJ (white plastic plate with screw cover), SJ (sachet water package), TJ (transparent plastic plate with pull-press cover), PJ (polythene pouch).

In Nigeria, these various packaging materials have not been utilized for local production of preserves for commercialization. A cursory survey of some retail markets revealed mainly the imported ones in glass jars. Thus, this work attempted to compare some quality parameters of mixed fruit Jam packed in different common packages in Nigeria, after a long storage period of 15 months.

\section{METHODOLOGY}

The different packaging containers used were obtained from a local market in Abuja. They were labeled as WJ (white plastic plate with screw cover), TJ (transparent plastic plate with pull-press cover), SJ (sachet water package), PJ (polythene pouch), as shown in figure 1; and GJ (glass jar).

\section{Sample preparation}

Watermelon and orange fruits were obtained from a local market in Abuja and pre-processed to remove the seeds, pit and rinds. Mixed-fruit Jam was then prepared according to the method of Fellows and Hampton (1992) as outlined in figure 2. Thereafter, the jam was filled into five (5) different packages made of plastic and polythene materials, and a fifth package of glass jar.

\section{Shelf life study}

The packaged samples were kept at room temperature and monitored every month for the first sign of deterioration, which is, liquid formation on the surface (Consumer Voice, 2015). After 15 months of storage, the samples were taken for comparative physical characteristics of $\mathrm{pH}$, moisture content and total soluble solids (TSS); and microbiological enumeration of total bacterial, total fungal and total coliform counts. The $\mathrm{pH}$ was measure with a $\mathrm{pH}$ meter while the moisture content and the TSS were determined by the oven-drying method. Total bacterial count was made after 24 hours of incubation at $37^{\circ} \pm 2^{\circ} \mathrm{C}$ on Nutrient agar, yeast and mould (fungal) count was made after 72 hours incubation at $28^{\circ} \pm 2^{\circ} \mathrm{C}$ on Potato Dextrose Agar (Akinyele and Oloruntoba, 2013), while the coliform count was made after 24 hours of incubation at $37^{\circ} \pm 2^{\circ} \mathrm{C}$ on MacConkey agar.

\section{Sensory evaluation}

The samples were subjected to organoleptic assessment by 10 panelists that are familiar with the product. The parameters assessed were consistency, appearance (colour), spreadability and overall acceptability. A 7-point hedonic scale was used to measure the respondents evaluations, from 1 (Disliked extremely) to 7 (Liked extremely). 


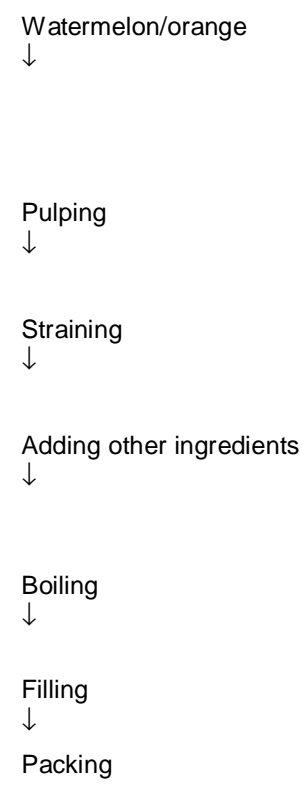

Figure 2. The flow chart for mixed Jam production. The figure shows the different stages involved in the production of Jam from combination of watermelon and orange fruits.

Table 1. Physical and Microbial Characteristics of packaged Jam samples after 15 months storage.

\begin{tabular}{|c|c|c|c|c|c|c|c|}
\hline Samples & $\mathrm{pH}$ & $\begin{array}{l}\text { Moisture } \\
\text { content }(\%)\end{array}$ & TSS (\%) & Total bacterial count (cfu/ml) & $\begin{array}{l}\text { Total Fungal count } \\
(\mathrm{cfu} / \mathrm{ml})\end{array}$ & $\begin{array}{l}\text { Coliform } \\
\text { (cfu/ml) }\end{array}$ & count \\
\hline SJ & 3.4 & 28 & 72 & 0 & 0 & 0 & \\
\hline PJ & 3.4 & 34 & 66 & 0 & 0 & 0 & \\
\hline GJ & 3.4 & 37 & 63 & 0 & 0 & 0 & \\
\hline WJ & 3.5 & 36 & 64 & 0 & 0 & 0 & \\
\hline TJ & 3.5 & 33 & 67 & 0 & $6 \times 10^{-2}$ & 0 & \\
\hline
\end{tabular}

\section{RESULT}

The virtual observation of the samples showed that there was loss of firmness in both samples packaged in sachet water and polythene pouch, while the other packages maintain their firmness. There was no appreciable darkening of the colour in each of the samples.

Table 1 shows the result of the physical parameters of $\mathrm{pH}$, moisture content, total soluble solids (TSS), and the microbiological enumeration of the different packaged samples after 15 months storage at room temperature. In table 2 , the mean scores of the sensory evaluation by ten (10) judges are presented.

\section{DISCUSSION}

As expected from the low $\mathrm{pH}$ values (3.4-3.5) of the samples and the high total soluble solids range (63-72\%), the samples' environmental conditions made it impossible for the proliferation of microorganisms. This was evident from the absence of bacteria, coliform and fungi in the packaged samples except for the transparent plastic plate, which exhibited a fungal growth of $6 \times 10^{2} \mathrm{cfu} / \mathrm{ml}$. This result agreed with Dauthy (1995) that all microorganisms are destroyed within the product during jam boiling, and if it is filled hot into clean receptacles which are subsequently sealed, and then inverted so that the hot jam contacts the lid surface,spoilage by microorganisms will not take place during storage.

Also, the total absence of coliform group in all the samples confirms the good sanitary condition of the Jam preparation process. Cornell University Department of Food Science (2007) indicated that one of the most common applications of coliform bacteria as indicator organisms is in their association with hygienic conditions and overall quality, especially concerning heat processed 
066 Afr. J. Food Sci. Technol.

Table 2. The Mean Scores of Sensory Evaluation Result.

\begin{tabular}{lllll}
\hline Samples & Appearance & Consistency & Spreadability & Overall acceptability \\
\hline GJ & $5.70 \pm 0.37^{\mathrm{b}}$ & $4.40 \pm 0.45^{\mathrm{c}}$ & $3.90 \pm 0.38^{\mathrm{d}}$ & $6.00 \pm 0.39^{\mathrm{j}}$ \\
PJ & $3.20 \pm 0.25^{\mathrm{a}}$ & $5.50 \pm 0.45^{\mathrm{e}}$ & $6.20 \pm 0.25^{\mathrm{h}}$ & $4.40 \pm 0.37^{\mathrm{i}}$ \\
SJ & $3.20 \pm 0.53^{\mathrm{a}}$ & $5.00 \pm 0.56^{\mathrm{d}}$ & $6.10 \pm 0.28^{\mathrm{h}}$ & $4.90 \pm 0.35^{\mathrm{i}}$ \\
WJ & $5.70 \pm 0.38^{\mathrm{b}}$ & $4.90 \pm 0.31^{\mathrm{d}}$ & $5.10 \pm 0.18^{\mathrm{g}}$ & $6.00 \pm 0.33^{\mathrm{j}}$ \\
TJ & $2.90 \pm 0.28^{\mathrm{a}}$ & $5.10 \pm 0.41^{\mathrm{d}}$ & $5.20 \pm 0.39^{\mathrm{g}}$ & $4.80 \pm 0.25^{\mathrm{i}}$ \\
\hline
\end{tabular}

The table shows that glass jar and white plastic plate with screw cover container were significantly $(p=0.05)$ more acceptable for packaging Jam spread than those in the other containers used.

Figures with the same letters along a column are not significantly different $(p=0.05)$. Key: WJ (white plastic plate with screw cover), TJ (transparent plastic plate with pull-press cover), SJ (sachet water package), PJ (polythene pouch) and GJ (glass jar).

foods, as they are killed by most heat processing conditions; therefore their presence in a food generally indicates an inadequate heat process or post-processing contamination.

Similarly, the fungal growth of $6 \times 10^{2} \mathrm{cfu} / \mathrm{ml}$ encountered in the transparent plastic plate was within the acceptable limit of $1 \times 10^{3} \mathrm{cfu} / \mathrm{ml}$ (Gulf Standard Organization, GSO, 2014).

The result of the sensory evaluation shows that the Jam packaged in the glass jar and white plastic plate with screw cover significantly retained their colour (appearance) better than the other packages used. In terms of consistency, the packaged Jam in polythene pouch was most preferred, closely followed by those in white plastic plate with screw cover, transparent plastic plate with pull-press cover and sachet water packages. Similarly, the most preferred for spreadability on bread are those packaged in sachet water package and polythene pouch, followed by white plastic plate with screw cover and transparent plastic plate with pull-press cover. Lastly, glass jar and white plastic plate with screw cover packages were significantly $(p=0.05)$ more acceptable for packaging Jam spread than those in the other packages used.

\section{CONCLUSION}

The comparative study showed that the use of some locally available containers for the aseptic packaging of Jam spread can adequately preserve it for a considerable period of storage at room temperature. Hence, it was concluded that some locally available containers can be used for packing small scale Jam production for commercialization.

\section{REFERENCES}

Akinyele BJ, Oloruntoba, OS (2013). Comparative Studies on Citrullus vulgaris, Citrullus Colocynthis and Cucumeropsis Mannii for Ogiri Production. British Microbiol. Res. J. 3(1): 1-18. Retrieved on 31st October 2015, from www.sciencedomain.org

Consumer Voice (2015). Comparative Test: Mixed-Fruit Jam. Retrieved on $11^{\text {th }}$ January 2015 from
http://consumeraffairs.nic.in/WriteReadData/userfiles/file/MixedFruitJam .pdf

CU-DFScience (2007). Coliform Bacteria - Indicators in Food \& Water Cornell University Department of Food Science Stocking Hall, Ithaca, New York 14853. Retrieved on $11^{\text {th }}$ January, 2015 from https://foodsafety.foodscience.cornell.edu/sites/foodsafety.foodscien ce.cornell.edu/files/shared/documents/CU-DFScience-NotesBacteria-Coliform-Indicators-09-07.pdf

Dauthy ME (1995). Fruit and vegetable processing. FAO Agricultural Services Bulletin: 119, Rome. Retrieved on $11^{\text {th }}$ January, 2015 from http://www.fao.org/docrep/V5030E/V5030E00.htm.

Fellows, P and Hampton A (1992). Small-scale food processing - A guide for appropriate equipment. Intermediate Technology Publications, London. Retrieved on $11^{\text {th }}$ January 2015 from www.fao.org/wairdocs/x5434e/x5434e05.htm

GSO (2014). Microbiological Criteria for Foodstuffs. GCC Standardization Organization. Retrieved on $11^{\text {th }}$ January, 2015 from https://www.gso.org.sa/gso-website/gso-website/activities/standards

UNIDO (2004). Small-scale Fruit and Vegetable Processing and Products. United Nations Industrial Development Organization Technology Manual. Vienna. Retrieved on $11^{\text {th }}$ January, 2015 from https://open.unido.org/api/documents/4672735/download/Smallscale $\% 20$ fruit $\% 20$ and $\% 20$ vegetable $\% 20$ processing $\% 20$ and $\% 20$ pro ducts\%2020Production\%20methods, \%20equipment\%20and\%20qu ality\%20assurance\%20practices 